\title{
Investigasi Pengetahuan Dan Pemahaman Anggota Dewan Perwakilan Rakyat Daerah (DPRD) tentang Penganggaran Berbasis Kinerja di Kota Bitung
}

\author{
JOSEPHIEN POLII ${ }^{1}$, LINTJE KALANGI ${ }^{2}$, LINDA LAMBEY ${ }^{3}$
}

\author{
${ }^{123}$ Program Magister Akuntansi, Fakultas Ekonomi dan Bisnis Universitas Sam Ratulangi \\ email: joe.polii.jp@gmail.com ${ }^{1}$, lintjekalangi@yahoo.com ${ }^{2}$, lindalambey@yahoo.com ${ }^{3}$
}

\begin{abstract}
The existence of budgetary reform in local financial management from traditional budget to performance budget requires DPRD members as executive partners to know and understand performance-based budgeting. This study is intended to investigate and obtain evidence empirically concerning knowledge and understandings of DPRD members on Performance-Based Budgeting and factors influencing them. It also includes the implementation of Performance-Based Budgeting in Bitung city. The study is a qualitative exploratory research. Respondents were chosen by purposive sampling. Data were collected by interviews, observation and documentation. Triangulation was conducted to validate data. This study concludes: (1). As many as 58\% DPRD members did not understand the concept of Performance-based budgeting; (2). Educational background and length of tenure do not affect the level of knowledge and understandings of the DPRD members; (3) they often to attend trainings and technical meetings but the results have not been fullest; (4). Legislative and Executive communicate to support implementation; (5). Obstacles found are regulation, group or personal interests, leader commitment, or implementation execution, limited budget and insufficient of elements and indicators.
\end{abstract}

Keywords: Knowledge, Understandings, Human Resources, Communication, Interests, Commitment

\begin{abstract}
Abstrak. Adanya reformasi penganggaran dalam pengelolaan keuangan daerah dari traditional budget ke performance budget menuntut anggota DPRD sebagai mitra eksekutif untuk mengetahui dan memahami apa itu penganggaran berbasis kinerja. Penelitian ini bertujuan untuk menginvestigasi dan memperoleh bukti secara empiris mengenai pengetahuan dan pemahaman Anggota DPRD tentang Penganggaran Berbasis Kinerja, dan faktor-faktor yang mempengaruhi pengetahuan dan pemahaman anggota DPRD tentang PBK serta implementasinya di Kota Bitung. Penelitian dilakukan dengan menggunakan metode penelitian kualitatif dengan pendekatan eksploratif (exploratory approach). Pemilihan responden menggunakan purposive sampling. Teknik pengumpulan data digunakan teknik wawancara, observasi dan dokumentasi. Untuk validitas data digunakan metode triangulasi. Berdasarkan hasil analisis dan pembahasan maka dapat disimpulkan bahwa: (1). Sebanyak 58\% dari anggota dewan cenderung tidak memahami konsep dasar dari penganggaran berbasis kinerja; (2). Latar belakang pendidikan dan lamanya masa jabatan tidak mempengaruhi tingkat pengetahuan dan pemahaman para anggota dewan; (3). Dalam meningkatkan kualitas sumber daya manusia pelatihan atau bimbingan teknis menjadi salah satu sarana yang sering diikuti oleh para anggota dewan tetapi hasilnya belum maksimal; (4). Komunikasi menjadi faktor pendukung ditahapan PBK dalam hubungan kemitraan antara legislatif dan eksekutif; (5). Regulasi, kepentingan pribadi atau kelompok, komitmen pimpinan atau pelaksana implementasi, keterbatasan anggaran serta tidak terpenuhinya elemen dan indikator PBK menjadi kendala dalam pelaksanaan PBK di Kota Bitung.
\end{abstract}

Kata Kunci: Pengetahuan, Pemahaman, SDM, Komunikasi, Kepentingan, Komitmen.

\section{Pendahuluan}

Undang-undang No. 23 Tahun 2014, Pasal 1 ayat 4 menyatakan bahwa Dewan Perwakilan Rakyat Daerah yang selanjutnya disingkat DPRD adalah lembaga perwakilan rakyat daerah yang berkedudukan sebagai unsur penyelenggara Pemerintah Daerah yang di dalamnya termasuk pengelolaan keuangan daerah. Peraturan Pemerintah Nomor 58 Tahun 2005 tentang Pengelolaan Keuangan Daerah, menjelaskan bahwa: (1) pengawasan atas keuangan daerah dilakukan oleh dewan, (2) serta adanya pemeriksaan terhadap pengelolaan keuangan daerah oleh eksternal yaitu Badan Pemeriksa Keuangan (BPK). Lembaga legislatif atau DPRD pada umumnya mempunyai tiga fungsi yaitu: (1) fungsi legislasi (fungsi membuat peraturan perundang-undangan), (2) fungsi anggaran (fungsi menyusun anggaran), (3) fungsi pengawasan (fungsi untuk mengawasi kinerja eksekutif).

DPRD menjalankan kewajibannya dalam menyerap, menghimpun dan menindaklanjuti aspirasi masyarakat yang diwakilinya dalam konteks menjalankan hak DRPD di bidang keuangan dan administrasi khususnya dalam hal pengelolaan anggaran pembangunan, bagi legislator yang telah 2 
(dua) kali masa jabatan pastinya sudah piawai dalam memahami dan mendalami substansi anggaran berbasis kinerja yang terkristaslisasi dalam bentuk Anggaran Pendapatan dan Belanja Daerah (APBD) namun bagi legislator yang baru memulai kiprahnya sebagai anggota DPRD tentunya membutuhkan waktu dan kemauan keras untuk beradaptasi agar menjadi anggota DPRD yang kredibel dan andal dalam mengemban amanat rakyat yang diwakilinya, baik melalui diklat fungsional maupun seminar pengembangan kapasitas anggota DPRD, semuanya itu tentu membutuhkan waktu. Namun kondisi lingkungan kerja seorang legislator saat ini dibutuhkan kecepatan dalam bertindak.

Pengetahuan DPRD tentang anggaran dapat diartikan sebagai pengetahuan dewan terhadap mekanisme penyusunan anggaran mulai dari tahap perencanaan sampai pada tahap pertanggungjawaban serta pengetahuan dewan tentang peraturan perundangan yang mengatur pengelolaan keuangan daerah. Pengetahuan DPRD tentang anggaran ini akan semakin penting apabila dikaitkan dengan mekanisme penyusunan dan penetapan APBD yang berlangsung saat ini. Selain itu pengawasan merupakan tahap integral dengan keseluruhan tahap pada penyusunan dan pelaporan APBD, pengawasan diperlukan pada setiap tahap bukan hanya pada tahap evaluasi saja (Mardiasmo, 2005). Menurut Alamsyah (1997) tujuan adanya pengawasan adalah untuk: (1) anggaran yang disusun benar-benar dijalankan, (2) menjaga agar pelaksanaan APBD sesuai dengan anggaran yang digariskan dan (3) menjaga agar pelaksanaan APBD dapat dipertanggungjawabkan.

Pengawasan dewan harus bersifat efektivitas, yang berarti tercapainya tujuan yang direncanakan yaitu melakukan pengawasan terhadap anggaran. Menurut Steers (1980) efektivitas adalah mengerjakan sesuatu dengan akurat, tepat waktu, objektif dan menyeluruh sesuai dengan tujuan organisasi. Setiap organisasi didirikan atau dibentuk untuk mengejar efektivitas, karena eksistensi dan pertumbuhan yang bersangkutan dapat mengemban misi dan melaksanakan tugasnya dengan tingkat ketangguhan yang tinggi. Menurut Parmono (2002) dalam penelitiannya menyimpulkan bahwa ada 2 (dua) faktor yang akan mempengaruhi pengawasan yang dilakukan dewan, pertama faktor internal, yang terdiri dari pengetahuan dewan tentang anggaran, latar belakang politik, keahlian, dan pengalaman. Sedangkan faktor kedua adalah faktor eksternal yaitu akuntabilitas dan transparansi. DPRD akan dapat memainkan peranannya dengan baik apabila pimpinan dan anggota-anggotanya berada dalam kualifikasi ideal, dalam arti memahami benar hak, tugas, dan wewenangnya dan mampu mengaplikasikannya secara baik, dan didukung dengan tingkat pendidikan dan pengalaman di bidang politik khususnya bagi mereka yang sudah memangku jabatan untuk periode yang kedua dan pemerintahan yang memadai.

Penganggaran Berbasis Kinerja (PBK) merupakan proses penyusunan Anggaran Pendapatan Belanja Daerah (APBD) yang diberlakukan dengan harapan dapat mendorong proses tata kelola pemerintahan yang lebih baik (Utomo et.al, 2007). Pada era sebelumnya, penentuan besarnya alokasi dana menggunakan incrementalism dan line item. Konsekuensi logis dari penerapan kedua pendekatan ini adalah penganggaran dibuat dengan muatan kira-kira yang lebih berorientasi pada selesainya kegiatan dan pertanggungjawaban keuangan tanpa peduli apakah hal itu menghasilkan nilai tambah, sesuai tujuan yang diinginkan, efektif dan efisien atau tidak. Penyusunan penerapan anggaran berdasarkan incrementalism/line item, sudah menjadi pola yang berakar dikalangan birokrasi, dari tim penyusunan anggaran maupun para aparat di Satuan Kerja Perangkat Daerah (SKPD) khususnya yang terlibat dalam perencanaan dan pengelolaan keuangan SKPD.

Permasalahan penerapan anggaran berbasis kinerja bukan hanya terjadi di Indonesia namun juga di banyak negara yang telah mencoba anggaran berbasis kinerja. Webb dan Candreva (2009) dalam studi kasusnya terhadap U.S.Navy menemukan bahwa penghambat keberhasilan implementasi penganggaran berbasis kinerja adalah sistem akuntansi yang tidak memadai serta kurangnya pengetahuan mengenai metode akuntansi biaya. Demikian pula, Aristrovnik dan Seljak (2009) dalam penelitiannya terhadap pengalaman-pengalaman dari negara-negara yang tergabung dalam OEDC, menyatakan bahwa reformasi menuju penganggaran berbasis kinerja membutuhkan waktu karena kelemahan dalam hal administrasi serta kurangnya pendekatan pemerintah terhadap organisasi publik pada level menengah dan bawah. Penerapan anggaran berbasis kinerja ini diperkuat oleh laporan Local Governance Support Program (2009) dalam pengawasan DPRD terhadap pelayanan publik yang menyatakan bahwa beberapa instrumen pertanggungjawaban kinerja dibuat secara sepihak, seperti Laporan Akuntabilitas Kinerja Instansi Pemerintah (LAKIP) cenderung terkesan hanya formalitas dan tidak cukup dapat diandalkan untuk menilai kinerja organisasi publik.

Penerapan penganggaran berbasis kinerja ini dimulai dari proses perencanaan yaitu penetapan rencana strategis. Rencana strategis merupakan kegiatan dalam mencari tahu dimana organisasi berada saat ini, arahan kemana organisasi menuju, dan bagaimana cara strategik untuk mencapai tujuan itu 
(BPKP, 2005). Rencana strategis memberikan petunjuk tentang mengerjakan sesuatu program/kegiatan yang benar (doing the right things) rencana strategis untuk mencapai tujuan dituangkan ke dalam rencana kinerja termasuk di dalamnya pembuatan target kinerja dengan menggunakan indikator/ukuran kinerja. Indikator kinerja dan target kinerja inilah yang harus digunakan dalam pembuatan RKA-SKPD sampai pada pelaksanaan APBD agar supaya proses pencapaian tujuan pada rencana startegis bisa tergambar dengan jelas.

Madjid dan Ashari (2013) menyatakan bahwa pemerintah di Indonesia telah melaksanakan anggaran berbasis kinerja tetapi belum utuh dan konsisten. Pada kenyataannya penerapan performance based budgeting hanya diikuti daerah pada tingkat perubahan teknis dan format, namun perubahan paradigma belum banyak terjadi (Rahayu et.al, 2007).

Dalam hal penganggaran, Pemerintah Kota Bitung telah menyesuaikan struktur APBD secara bertahap sesuai dengan peraturan perundangan yang berlaku yaitu Undang-Undang No. 17 Tahun 2003 tentang Keuangan Negara yang menyatakan bahwa setiap instansi pemerintah termasuk Sekretariat DPRD dan DPRD diwajibkan untuk merancang dan mengelola anggaran berbasis kinerja. Namun disadari pada praktiknya Pemerintah Kota Bitung belum sepenuhnya menerapkan penganggaran berbasis kinerja. Kenyataan yang ada di lapangan, program dan kegiatan dari SKPD, masih sangat dipengaruhi oleh program dan kegiatan yang telah dikerjakan pada tahun-tahun yang lalu. Demikian pula dengan penentuan besarnya anggaran belum sepenuhnya mengacu pada target kinerja berupa output dan outcome.

Dari data bimtek dan produk perda yang dihasilkan pada tahun 2016, para anggota DPRD mengikuti pelatihan/bimtek tentang keuangan dengan frekuensi yang lebih banyak dibanding tahun 2014 dan 2015. Tetapi penetapan perda APBD 2017, tanggal 30 Desember 2016 mendekati pada batas akhir waktu yang ditetapkan dalam Permendagri No. 13 Tahun 2006 tentang Pedoman Pengelolaan Keuangan Daerah yaitu tanggal 31 Desember. Berbeda dengan tahun 2014 dan tahun 2015 dilakukan pada bulan Oktober dan September lebih awal dari dari tahun 2016.

Penelitian untuk anggota dewan (legislatif) perlu diteliti, karena tugas anggota dewan yang merupakan pelaku utama pengambil keputusan terkait dengan pengesahan dan pengawasan anggaran kinerja. DPRD Kota Bitung terdiri dari 30 (tiga puluh) orang anggota dengan latar belakang pendidikan yang bervariasi, yaitu sebanyak 2 (dua) orang Strata Dua (S2) yaitu Master dalam bidang teologi dan Master dalam bidang sains, sebanyak 12 (dua belas) orang Strata Satu (S1) yang terdiri dari Sarjana Ekonomi 3 (tiga) orang, Sarjana Hukum 4 (empat orang), Sarjana Pendidikan 2 (dua) orang, Sarjana Sosial dan Sarjana Tehnik masing-masing 1 (satu) orang. Sisanya sebanyak 15 (lima belas) orang dengan jenjang pendidikan Sekolah Menengah Atas / Setara (SMA). Selain itu sebanyak 8 (delapan) orang telah menjadi anggota DPRD selama dua periode.

Latar belakang profesi para anggota DPRD ada yang sebagai pengusaha, pensiunan PNS, ibu rumah tangga yang merupakan kader partai yang disiapkan untuk menjadi anggota legislatif. Berdasarkan latar belakang pendidikan dan profesi yang beragam maka pengetahuan dan pemahaman tentang tugas dan kewajiban sebagai anggota dewan juga pasti beragam.

Tujuan penelitian ini untuk: 1). menginvestigasi dan memperoleh bukti secara empiris mengenai pengetahuan dan pemahaman Anggota DPRD tentang penganggaran berbasis kinerja; 2) mengetahui faktor-faktor apa yang mempengaruhi pengetahuan dan pemahaman anggota DPRD tentang PBK serta implementasi PBK di Kota Bitung.

\section{Model Analisis}

Model analisis pada penelitian ini dimulai dengan telaah paradigma melalui kajian isu-isu empirik tentang penganggaran berbasis kinerja dan langkah berikut adalah fokus penelitian tentang pengetahuan dan pemahaman anggota DPRD Kota Bitung yang didukung dengan studi kepustakaan serta tahapan survey awal, selanjutnya adalah tahapan pengumpulan data, pengolahan data, periksa keabsahan data dan penyusunan laporan penelitian. 
Gambar 1. Model Analisis

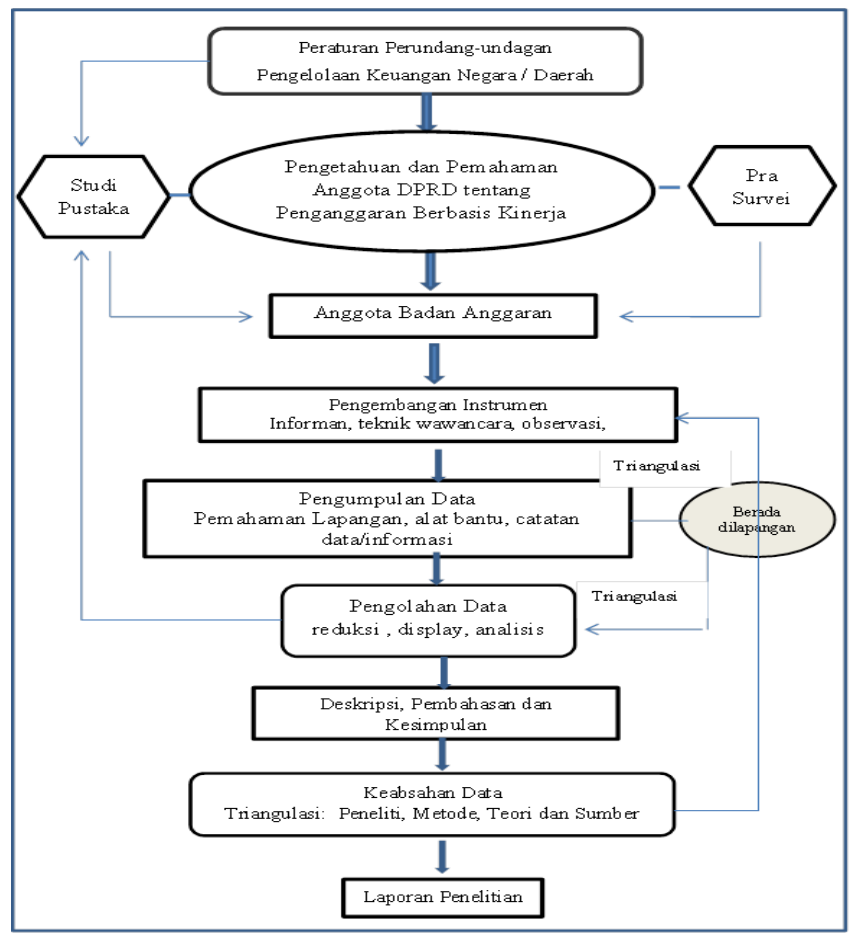

\section{Metode Penelitian}

Penelitian berdasarkan tujuannya terdiri dari penelitian dasar (basic research) dan penelitian terapan (applied research). Penelitian Dasar (basic research) disebut juga penelitian murni (pure research) atau penelitian pokok (fundamental research) adalah penelitian yang diperuntukkan bagi pengembangan suatu ilmu pengetahuan serta diarahkan pada pengembangan teori-teori yang ada atau menemukan teori baru. Penelitian ini lebih diarahkan untuk mengetahui, menjelaskan, dan memprediksikan fenomena-fenomena alam dan sosial. Tujuan penelitian dasar adalah untuk menambah pengetahuan dengan prinsip-prinsip dasar, hukum-hukum ilmiah, serta untuk meningkatkan pencarian dan metodologi ilmiah.

Penelitian terapan adalah penelitian yang mempunyai alasan praktis, keinginan untuk mengetahui, bertujuan agar dapat melakukan sesuatu yang jauh lebih baik, lebih efektif, dan efisien. Penelitian terapan atau applied research dilakukan berkenaan dengan kenyataan-kenyataan praktis, penerapan, dan pengembangan ilmu pengetahuan yang dihasilkan oleh penelitian dasar dalam kehidupan nyata. Penelitian terapan berfungsi untuk mencari solusi tentang masalah masalah tertentu. Tujuan utamanya adalah pemecahan masalah sehingga hasil penelitian dapat dimanfaatkan untuk kepentingan manusia baik secara individu atau kelompok maupun untuk keperluan industri atau politik dan bukan untuk wawasan keilmuan semata.

Penelitian yang digunakan adalah penelitian terapan (applied research) dengan metode penelitian kualitatif pendekatan eksploratif (exploratory approach). Metode kualitatif ini dipilih agar data yang diperoleh akan lebih lengkap, lebih mendalam, kredibel dan bermakna sehingga tujuan penelitian dapat dicapai. Sementara metode eksploratori menurut Arikunto (2010:32), adalah metode penelitian yang bertujuan untuk menggali suatu informasi. Amirin (2009) mengatakan penelitian eksploratif merupakan salah satu pendekatan penelitian yang digunakan untuk meneliti sesuatu (yang menarik perhatian) yang belum diketahui, belum dipahami, belum dikenali, dengan baik.

Teknik pengumpulan data yag ditempuh dalam penelitian ini adalah melalui wawancara mendalam (in-depth interview), observasi (non participant observation) dan studi dokumentasi (documentation). Selanjutnya, uji keabsahan data dalam penelitian ini meliputi triangulasi peneliti, triangulasi teori dan triangulasi sumber data.

Analisis data dimulai dengan menggunakan content analysis yaitu membuat transkrip hasil wawancara, dengan cara memutar kembali rekaman hasil wawancara, mendengarkan dengan saksama, kemudian menuliskan kata-kata yang didengar sesuai dengan apa yang ada di rekaman tersebut. Langkah selanjutnya dari analisis data kualitatif yang digunakan dalam penelitian ini adalah Teknik 
Analisis Isi menurut Model Miles dan Huberman. Aktivitas analisis data Miles and Huberman (1984) dalam Satori dan Komariah (2014:218) terdiri atas: data reduction, data display dan conclusion drawing/verification yang dilakukan secara interaktif dan berlangsung secara terus menerus sampai tuntas, sehingga datanya mencapai jenuh. Analisis data pada penelitian ini dikembangkan dengan editing, kategorisasi/coding dan meaning (Musfiqon, 2012).

\section{Analisis dan Pembahasan}

Penelitian dilaksanakan di Kantor DPRD Kota Bitung selama \pm 4 (empat) bulan yakni antara bulan Mei sampai bulan Agustus 2017. Instrumen pendukung yang digunakan adalah: buku catatan (notebook), pedoman wawancara, alat perekam berupa audio (voice recorder) / video recorder (handycam) untuk merekam pelaksanaan wawancara dengan informan yang hasilnya di transcribe menjadi transkrip data, kamera untuk mendokumentasikan kegiatan penelitian di lapangan, dan laptop untuk menunjang penulisan hasil penelitian.

\section{Pengetahuan dan Pemahaman anggota DPRD Kota Bitung tentang Penganggaran Berbasis Kinerja.}

Penganggaran berbasis kinerja (performance budgeting) dalam keuangan Negara RI, disebutkan dalam pasal 14 ayat (2) UU No. 17 Tahun 2003 tentang Keuangan Negara. Secara teori, prinsip anggaran berbasis kinerja adalah anggaran yang menghubungkan anggaran dengan hasil yang diinginkan (output dan outcome) sehingga setiap rupiah yang dikeluarkan dapat dipertanggungjawabkan kemanfaatannya (Widiyantoro, 2009). Sebagian besar dari anggota badan anggaran DPRD tidak memahami dengan baik hakikat dari penganggaran berbasis kinerja serta apa itu anggaran berbasis kinerja. Tingkat pendidikan dan lamanya masa jabatan tidak membuat tingkat pengetahuan dan pemahaman para anggota dewan tentang PBK menjadi baik. Menurut Sudjana (1992) pemahaman dapat dibedakan kedalam 3 kategori, yaitu : (1) tingkat terendah adalah pemahaman terjemahan, mulai dari menerjemahkan dalam arti yang sebenarnya, mengartikan dan menerapkan prinsip-prinsip, (2) tingkat kedua adalah pemahaman penafsiran yaitu menghubungkan bagian-bagian terendah dengan yang diketahui berikutnya atau menghubungkan beberapa bagian grafik dengan kejadian, membedakan yang pokok dengan yang tidak pokok dan (3) tingkat ketiga merupakan tingkat pemaknaan ekstrapolasi. Memiliki pemahaman tingkat ekstrapolasi berarti seseorang mampu melihat dibalik yang tertulis, dapat membuat estimasi, prediksi berdasarkan pada pengertian dan kondisi yang diterangkan dalam ide-ide atau simbol, serta kemampuan membuat kesimpulan yang dihubungkan dengan implikasi dan konsekuensinya.

Tingkat pemahaman ekstrapolasi dibutuhkan para anggota DPRD dalam memahami penganggaran berbasis kinerja yang adalah suatu sistem penyusunan anggaran yang berdasarkan prestasi kerja atau anggaran berbasis kinerja sebagaimana tertuang dalam Undang-Undang No. 17 Tahun 2003 tentang Keuangan Negara dan dalam Permendagri No. 13 Tahun 2006 tentang Syarat Pengelolaan Keuangan Daerah menyatakan Anggaran Berbasis Kinerja yang optimal harus memenuhi 5 pedoman: Indikator Kinerja, Capaian / Target Kinerja, Standar Satuan Harga (dokumen sejenis), Standar Pelayanan Minimal (SPM) dan Analisis Standar Belanja.

Pemerintah Kota Bitung dalam pelaksanaan penganggaran berbasis kinerja dinilai oleh anggota DPRD telah memenuhi indikator kinerja dengan mendasarkan penyusunan anggaran sesuai aturan, rencana strategis serta visi, misi, tujuan dan sasaran pemerintah kota serta sesuai tahapannya. Anggaran berbasis kinerja bergantung pada kerangka kerja umum untuk mengukur hasil. Kerangka kerja tersebut mencakup (Widiyantoro, 2009):

1. Pernyataan Visi atau Misi - pilihan masa depan tentang tujuan keberadaan suatu organisasi;

2. Tujuan - Hasil dari suatu upaya yang ditetapkan;

3. Sasaran - langkah spesifik untuk mencapai tujuan;

4. Ukuran - Indikator kuantitatif atau kualitatif digunakan untuk menilai kinerja atau pencapaian tujuan, meliputi: outcome, output, efisiensi, input, kualitas dan penjelasan.

\section{Faktor - faktor yang mempengaruhi pengetahuan dan pemahaman anggota DPRD tentang PBK di Kota Bitung.}

Sumber daya manusia adalah potensi yang menjadi motor penggerak organisasi, baik organisasi swasta maupun organisasi publik. Anggota DPRD pun adalah sumber daya manusia yang dalam melaksanakan tugas dan tanggung jawabnya perlu mempunyai kualitas. Kualitas SDM harus selalu ditingkatkan dengan salah satu cara yaitu dengan mengikuti pelatihan atau bimbingan teknis. 
Menurut para anggota DPRD, bimbingan teknik/ bimtek sangat diperlukan untuk menambah pengetahuan dan pemahaman tentang suatu aturan / regulasi. Pelaksanaan konsultasi dan kunker juga menurut mereka bisa menjadi sarana peningkatan wawasan anggota DPRD, akan tetapi pada pelaksanaannya, kinerja yang ingin dicapai masih belum maksimal, karena kegiatan yang dilakukan sebagian besar hanya untuk penyerapan anggaran tanpa melihat manfaat yang perlu dicapai. Itu juga menjadi kendala dalam meningkatkan pengetahuan dan pemahaman anggota DPRD tentang anggaran berbasis kinerja

Kualitas SDM menurut Notoatmodjo dalam bukunya yang berjudul "Pengembangan Sumber Daya Manusia”, adalah menyangkut dua aspek yaitu aspek fisik (kualitas fisik) dan aspek non fisik (kualitas non fisik) yang menyangkut kemampuan bekerja, berpikir dan keterampilan”. Sedangkan menurut pendapat dari Raharjo (1992) dalam bukunya yang berjudul "Intelektual, Intelegensia dan perilaku politik bangsa", kualitas sumber daya manusia itu tidak hanya ditentukan oleh aspek keterampilan atau kekuatan tenaga fisiknya saja, akan tetapi juga ditentukan oleh pendidikan atau kadar pengetahuannya, pengalaman atau kematangannya dan sikapnya serta nilai-nilai yang dimilikinya. Dan beliau juga mengatakan bahwa aspek biologi juga memiliki peran dan arti penting bagi peningkatan kualitas sumber daya manusia.

Teori motivasi menurut MC Clelland dalam Reksohadiprojo dan Handoko (1996), individu dapat memiliki motivasi jika memang dirinya memiliki keinginan untuk berprestasi lebih baik dibandingkan lainnya. Terdapat 3 kebutuhan yang dijelaskan di dalam teori ini.

1. Kebutuhan prestasi yang tercermin dari keinginannya untuk mengambil tugas yang bisa dipertanggung jawabkan secara individu. Dalam hal ini, seseorang harus bisa menentukan tujuan yang logis dengan memperhitungkan risiko yang ada serta melakukannya secara kreatif dan inovatif.

2. Kebutuhan Afiliasi.

3. Kebutuhan Kekuasaan, kebutuhan ini dapat terlihat pada diri seseorang yang ingin memiliki pengaruh atas diri orang lain. Mereka haruslah peka terhadap struktur pengaruh antara satu sama lainnya, bahkan mencoba untuk menguasai orang tersebut hingga mengatur tingkah lakunya

\section{Faktor - faktor yang mempengaruhi Implementasi PBK di Kota Bitung.}

\section{Regulasi}

Regulasi bisa juga menjadi kendala dalam pelaksanaan anggaran berbasis kinerja dapat dijelaskan dengan contoh tentang penyusunan APBD, dimana sejak tahapan awal perencanaan pihak legislatif telah menyetujui rancangan yang diserahkan oleh pihak eksekutif yang dianggap sudah merupakan anggaran yang berbasis kinerja, untuk dilaksanakan selama satu tahun, namun biasanya masih dalam perjalanan masa anggaran telah terjadi pergeseran dan nantinya sebagai dasar perubahan APBD yang sebenarnya malah merubah capaian kinerja dari program kegiatan yang telah direncanakan pada tahap awal. Pergeseran terjadi karena ada kepentingan dan karena ada regulasi yang mengatur tentang pelaksanaan perubahan anggaran.

Menurut Scott (2009) terdapat dua teori regulasi yaitu public interest theory dan interest group theory. Public interest theory menjelaskan bahwa regulasi harus dapat memaksimalkan kesejahteraan sosial dan interest group theory menjelaskan bahwa regulasi adalah hasil lobi dari beberapa individu atau kelompok yang mempertahankan dan menyampaikan kepentingan mereka kepada pemerintah.

Teori regulasi disampaikan oleh Stigler (1971) yang mengatakan bahwa aktivitas seputar peraturan menggambarkan persaudaraan diantara kekuatan politik dari kelompok berkepentingan (eksekutif/industri) sebagai sisi permintaan/demand dan legislatif sebagai supply. Teori ini berpendapat bahwa dibutuhkan aturan-aturan atau ketentuan dalam akuntansi. Pemerintah dibutuhkan peranannya untuk mengatur ketentuan-ketentuan terhadap apa yang harus dilakukan perusahaan untuk menentukan informasi. Ketentuan diperlukan agar semuanya baik pemakai maupun penyaji mendapatkan informasi yang sama dan seimbang.

\section{Kepentingan}

Pelaksanaan penganggaran berbasis kinerja yang seharusnya difokuskan pada pencapaian kinerja dengan output dan outcome yang jelas, seringkali dipengaruhi oleh konflik kepentingan dalam proses/tahapan penganggaran berbasis kinerja tersebut. Untuk menjalankan tugas dan wewenangnya sebagai anggota DPRD sebagaimana diamanatkan dalam Undang-Undang Republik Indonesia Nomor 17 Tahun 2014 tentang Majelis Permusyawaratan Rakyat, Dewan Perwakilan Rakyat, Dewan 
Perwakilan Daerah, Dan Dewan Perwakilan Rakyat Daerah, anggota DPRD atau legislator mempunyai hubungan keagenan / hubungan kontrak dengan eksekutif seperti yang dinyatakan teori Agency (Jensen and Meckling. 1976). Hubungan tersebut terkadang menimbulkan masalah diantara kedua pihak yang melakukan kontrak. Masalah ini terjadi karena manusia adalah makhluk ekonomi yang mempunyai sifat dasar untuk mementingkan kepentingan diri sendiri. Legislatif dan eksekutif memiliki tujuan yang berbeda dan keduanya menginginkan agar tujuan tersebut terpenuhi. Hal ini mengakibatkan munculnya konflik kepentingan.

Faktor kepentingan baik pribadi maupun kelompok dari legislatif dan eksekutif menjadi faktor kendala dalam pencapaian tujuan dari penganggaran berbasis kinerja. Hasil penelitian ini mendukung penelitian Saifuddin et.al (2001) yang menyimpulkan bahwa anggota dewan memaknai implementasi anggaran kinerja sebagai kepentingan dan konflik struktural.

\section{Disposisi atau Sikap}

Salah satu faktor yang mempengaruhi pelaksanaan penganggaran berbasis kinerja adalah disposisi atau sikap dari pelaksana kebijakan itu tersebut. Disposisi adalah watak atau karakteristik yang dimiliki oleh implementor, seperti komitmen, kejujuran dan sifat demokrasi. Dalam pencapaian tujuan dari penganggaran berbasis kinerja komitmen dari pelaksana kebijakan menjadi salah satu kendala.

Menurut Van Meter dan Van Horn (1975), ada enam variabel yang mempengaruhi kinerja implementasi, yakni: (1) standar dan sasaran kebijakan; (2) sumber daya; (3) komunikasi antar organisasi dan penguatan aktivitas; (4) karakteristik agen pelaksana; (5) disposisi implementor; (6) kondisi sosial, ekonomi dan politik.

1. Standar dan sasaran kebijakan. Setiap kebijakan publik harus mempunyai standar dan suatu sasaran kebijakan jelas dan terukur. Dengan ketentuan tersebut tujuannya dapat terwujudkan. Dalam standar dan sasaran kebijakan tidak jelas, sehingga tidak terjadi multi-interpretasi dan mudah menimbulkan kesalah-pahaman dan konflik di antara para agen implementasi.

2. Sumber daya. Dalam suatu implementasi kebijakan perlu dukungan sumber daya, baik sumber daya manusia (human resources) maupun sumber daya materi (material resources) dan sumber daya metode (method resources). Dari ketiga sumber daya tersebut, yang paling penting adalah sumber daya manusia, karena di samping sebagai subjek implementasi kebijakan juga termasuk objek kebijakan publik.

3. Hubungan antar organisasi. Dalam banyak program implementasi kebijakan, sebagai realitas dari program kebijakan perlu hubungan yang baik antar instansi yang terkait, yaitu dukungan komunikasi dan koordinasi. Untuk itu, diperlukan koordinasi dan kerja sama antar instansi bagi keberhasilan suatu program tersebut. Komunikasi dan koordinasi merupakan salah satu urat nadi dari sebuah organisasi agar program-programnya tersebut dapat direalisasikan dengan tujuan serta sasarannya.

4. Karakteristik agen pelaksana. Dalam suatu implementasi kebijakan agar mencapai keberhasilan maksimal harus diidentifikasikan dan diketahui karakteristik agen pelaksana yang mencakup struktur birokrasi, norma-norma, dan pola-pola hubungan yang terjadi dalam birokrasi, semua itu akan mempengaruhi implementasi suatu program kebijakan yang telah ditentukan.

5. Disposisi implementor. Dalam implementasi kebijakan sikap atau disposisi implementor ini dibedakan menjadi tiga hal, yaitu; (a) respons implementor terhadap kebijakan, yang terkait dengan kemauan implementor untuk melaksanakan kebijakan publik; (b) kondisi, yakni pemahaman terhadap kebijakan yang telah ditetapkan; dan (c) intens disposisi implementor, yakni preferensi nilai yang dimiliki tersebut.

6. Kondisi lingkungan sosial, politik dan ekonomi. Variabel ini mencakup sumber daya ekonomi lingkungan yang dapat mendukung keberhasilan implementasi kebijakan, sejauh mana kelompok-kelompok kepentingan memberikan dukungan bagi implementasi kebijakan; karakteristik para partisipan, yakni mendukung atau menolak; bagaimana sifat opini publik yang ada di lingkungan dan apakah elite politik mendukung implementasi kebijakan.

\section{Masalah Anggaran Berbasis Kinerja}

Faktor-faktor yang menjadi kendala dari yang pelaksanaan PBK terletak pada ketidak sesuaian antara perencanaan dan hasil yang ingin dicapai, keterbatasan anggaran dan fokus pada seberapa besar anggaran belanja khususnya telah diserap. Dalam evaluasi pun terlihat bahwa yang dibahas memang hanya jumlah penyerapan anggaran dari tiap SKPD tidak sampai pada kinerja yang ingin dicapai. 
Menurut Mahmudi (2005) tujuan pengukuran kinerja adalah (1) mengetahui tingkat ketercapaian tujuan organisasi, (2) menyediakan sarana pembelajaran bagi pegawai, (3) memperbaiki kinerja periode berikutnya, (4) memberikan pertimbangan yang sistematik dalam pembuatan keputusan pemberian reward dan punishment, (5) memotivasi pegawai, (6) menciptakan akuntabilitas publik. Jadi dengan perspektif ini yang jadi pokok dari anggaran adalah tujuannya atau misi anggaran tersebut dimanfaatkan. Dalam konsep ini, bahwa setiap output dan outcome sebuah kegiatan yang dilakukan oleh pemerintah akan dihitung kelayakan penggunaan anggarannya, sehingga akan menimbulkan efisiensi dan rasionalitas dalam pengelolaan anggaran.

\section{Komunikasi}

Komunikasi juga menjadi faktor pendukung dalam implementasi PBK di Kota Bitung. Dalam tahapan penyusunan anggaran yang berbasis kinerja, membangun komunikasi antara lembaga eksekutif dan lembaga legislatif perlu adanya hubungan timbal balik. Guna terciptanya kerja yang baik untuk rakyat maka dalam hal ini perlu dilakukan pembagian kerja yang jelas dimana legislatif (DPRD) memiliki tugas dalam membuat Peraturan Daerah (Perda), membuat anggaran, dan menjadi alat kontrol eksekutif. Dan yang lebih penting DPRD itu bisa menjalin komunikasi antara masyarakat, Pemerintah Daerah, dan Pemerintah Pusat yang lebih tinggi, dan semua itu perlu adanya saluran komunikasi politik. Tujuannya untuk menyampaikan apa yang sudah DPRD dilakukan dan apa yang akan dilakukan oleh DPRD.

Komunikasi yang baik akan menciptakan hubungan yang baik antara legislatif dan eksekutif. Dalam penganggaran berbasis kinerja pada tahapan perencanaan penyusunan anggaran, khususnya anggaran untuk program kegiatan DPRD, komunikasi selalu dilakukan para anggota DPRD dengan pihak pemerintah dalam hal ini sekretariat dewan demikian juga dengan SKPD sebagai mitra kerja DPRD.

Goldhaber (1990) memberi definisi komunikasi organisasi adalah proses menciptakan dan saling menukar pesan dalam satu jaringan hubungan yang saling tergantung satu sama lain untuk mengatasi lingkungan yang tidak pasti atau selalu berubah-ubah. Definisi ini mengandung tujuh konsep kunci yaitu proses, pesan, jaringan, saling tergantung, hubungan, lingkungan dan ketidakpastian.

\section{Penutup}

Kesimpulan Penelitian ini adalah: 1) Sebanyak 58\% dari anggota DPRD yang menjadi infoman tersebut cenderung tidak memahami konsep dasar dari penganggaran berbasis kinerja. PBK dipahami sebagai anggaran yang bertujuan mencapai kinerja, tapi apa itu kinerja belum sepenuhnya mereka pahami. Kinerja yang mereka pahami adalah bahwa anggaran yang telah disusun telah dilaksanakan sebesar berapa anggaran yang telah terserap untuk suatu program kegiatan; 2). Latar belakang pendidikan dan lamanya masa jabatan tidak mempengaruhi tingkat pengetahuan dan pemahaman para anggota dewan; 3) Dalam meningkatkan kualitas sumber daya manusia khususnya peningkatan pengetahuan dan pemahaman, pelatihan atau bimbingan teknis menjadi salah satu sarana yang sering diikuti oleh para anggota dewan. Namun dalam pelaksanaannya program peningkatan kemampuan belum memberikan hasil yang maksimal dan terkesan hanya untuk realisasi penyerapan anggaran program kegiatan tersebut; 4) Komunikasi menjadi faktor pendukung dalam tahapan PBK dalam hubungan kemitraan antara legislatif dan eksekutif; 5) Kepentingan pribadi atau kelompok, komitmen pimpinan atau pelaksana implementasi, keterbatasan anggaran serta tidak terpenuhinya elemen dan indikator PBK dalam evaluasinya menjadi kendala dalam pelaksanaan PBK di Kota Bitung. Evaluasi yang dilakukan tidak sampai pada pencapaian kinerja yang sebenarnya berupa output dan outcome atau tujuan yang ingin dicapai dari suatu program kegiatan, melainkan hanya evaluasi realisasi penyerapan anggaran.

Saran yang dapat diberikan dari penelitian ini: 1) Perlunya adanya metode peningkatan kapasitas SDM yang tepat bagi para anggota DPRD melalui Bimtek/Diklat/Kursus khususnya dalam pelaksanaan PBK, sehingga para anggota DPRD bisa lebih memahami PBK sesuai teori sampai pada tahapan pelaksanaan sesuai regulasi bukan hanya berdasarkan pengetahuan yang berasal dari pengalaman pelaksanaan tugas sehingga apa yang telah dibahas dan diputuskan bersama dengan eksekutif dalam evaluasi pelaksanaannya dapat dipertanggung-jawabkan sesuai peraturan perundangundangan; 2). Para anggota DPRD perlu memahami secara jelas kinerja apa yang ingin dicapai dalam PBK sehingga faktor-faktor penghambat atau kendala -kendala dalam PBK bisa dikurangi atau bahkan dihilangkan; 3). Perlunya komitmen yang kuat antara legislatif dan eksekutif dalam pencapaian tujuan pelaksanaan PBK; 4). Untuk penelitian selanjutnya, perlu adanya penelitian tentang penyebab 
ketidakpahaman para anggota DPRD tentang penganggaran terkait pengaruh kompetensi dan politik/partai.

\section{Daftar Pustaka}

Alamsyah. 1997. Mekanisme Pengawasan APBD di Kabupaten Sleman, Tesis MAP. UGM, Yogyakarta

Aira A. 2011. Pengaruh Pengetahuan Anggota DPRD Tentang Anggaran Terhadap Efektivitas Pengawasan Anggaran (Studi Empiris Pada Kabupaten Kampar). Artikel dipublikasikan Universitas Islam Negeri Sulthan Syarif Kasim Riau.

Aristovnik, Aleksander and Seljak, Janko. 2009. "Performance Budgeting: Selected International Experiences and Some Lessons for Slovenia”. MPRA Paper No. 15499, 31 Mei 2009

Arikunto, Suharsimi. 2010. Prosedur Penelitian : Suatu Pendekatan Praktik. Rineka Cipta: Jakarta.

Amirin, Tatang M. 2009. "Penelitian eksploratori (eksploratif)." tatangmanguny.wordpress.com.

Badan Pemeriksa Keuangan Republik Indonesia. 2017. Laporan Hasil Pemeriksaan atas Kepatuhan Terhadap Ketentuan Peraturan Perundang-undangan Pemerintah Daerah Kota Bitung.

Badan Pengawasan Keuangan dan Pembangunan (BPKP). 2007. Pusat Penelitian dan Pengembangan Pengawasan. Anggaran Berbasis Kinerja.

Badan Pengawasan Keuangan dan Pembangunan (BPKP). 2005. Pedoman Penyusunan Anggaran Berbasis Kinerja (Revisi). Jakarta.

George C Edwards 1980, Implementing public policy (Politics and public policy series), Congressional Quarterly Press

Goldhaber, G.M. 1990. Organizational Communication $5^{\text {Th }}$ Edition, Dubuque, Iowa: W.C. Brown.

Jensen, M. C and Meckling, W.H. 1976. Theory of the Firm : Managerial Behavior, Agency Costs and Ownership Structure. Journal of Financial Economics, Oktober, 1976.

Kathleen M. Eisenhardt (1989). Agency Theory: An Assessment and Review. Academy of Management Review.

Local Governance Support Program. 2009. Penerapan Anggaran Berbasis Kinerja. USAID.

Mahmudi. 2005. Manajemen Kinerja Sektor Publik. UPP YKPN: Yogyakarta.

Madjid N.C dan Ashari H. 2013. Analisis Implementasi Anggaran Berbasis Kinerja (Studi Kasus pada Badan Pendidikan dan Pelatihan Keuangan), Kementerian Keuangan Republik Indonesia Badan Pendidikan dan Pelatihan Keuangan

Mardiasmo. 2005. Akuntansi Sektor Publik. Penerbit Andi: Yogyakarta.

Musfiqon. 2012. Panduan Lengkap Metodologi Penelitian Pendidikan. PT. Prestasi Pustakaraya: Jakarta.

Notoatmodjo, S. 2003. Pengembangan Sumber Daya Manusia. Penerbit Rineka Cipta: Jakarta.

Parmono. A. 2002. Pengawasan Legislatif terhadap Eksekutif dalam Penyelenggaraan Pemerintah Daerah. Tesis S2 Tidak di Publikasikan. Program Pasca Sarjana Ilmu Administrasi Negara, Universitas Brawijaya: Malang.

Raharjo. 1992. Intelektual, Inteligensia dan Perilaku politik bangsa. Penerbit Kompas.

Rahayu S, Unti Ludigdo, Didied Afandy 2007, "Studi Fenomenologis terhadap Proses Penyusunan Anggaran Daerah (Bukti Empiris dari Satu Satuan Kerja Perangkat Daerah di Propinsi Jambi)", Simposium Nasional Akuntansi X.

Republik Indonesia. Undang-Undang Republik Indonesia Nomor 17 Tahun 2003, Keuangan Negara. . Peraturan Menteri Dalam Negeri Nomor 13 Tahun 2006, Pedoman Pengelolaan Keuangan Daerah. .Peraturan Pemerintah Nomor 58 Tahun 2005 tentang Pengelolaan Keuangan Daerah. Daerah.

Reksohadiprodjo S dan Handoko.1996. Organisasi Perusahaan. Edisi kedua. BPFE: Yogyakarta. Satori D dan Komariah A. 2014. Metodologi Penelitian Kualitatif. Alfabeta: Bandung. Scott, William R. 2003. Financial Accounting Theory . Prentice Hall Inc: New Jersey.

Setyawati, Yuni (2010). Pengaruh Pengetahuan Anggaran Anggota Dewan terhadap Pengawasan Keuangan Daerah (APBD) dengan Partisipasi Masyarakat dan Transparasi Kebijakan Publik sebagai variabel pemoderasi, (Studi Empiris di Karesidenan Surakarta). Tesis, Universitas Sebelas Maret Surakarta. 
Steers, Richard M. 1980. Efektivitas Organisasi. Terj: Magdalena Jamin. Erlangga. Jakarta.

Stigler, J.G. 1971. The Theory of Economic Regulation, Bell Journal of Management Science, 2 (1), Spring.

Sudjana. N. 1992. Penilaian Hasil Proses Belajar Mengajar. PT.Remaja Rosdakarya: Bandung.

Utomo D C, Yuwono S, H Suheiry Zein dan H. Azrafiany A.R 2007, APBD dan Permasalahannya (Panduan Pengelolaan Keuangan Daerah), Penerbit Bayumedia Publishing

Van Meter, Donald S. dan Carl E. Van Horn. 1975.The Policy Implementation Process: A Conceptual Framework. State University: Ohio.

Webb, Natalie J. and Candreva, Philip J. 2009. Diagnosing Performance Management and Performance Budgeting System: A Case Study of The US Navy. MPRA Paper, No. 14754. 09 Maret 2009.

Widiyantoro, A, E. 2009. Implementasi Performance Budgeting : Sebuah Kajian Fenomenologis (Studi Kasus Pada Universitas Diponegoro). 